\title{
Analysis of the Consciousness and Role Creation of Film and Television Animation
}

\author{
Ziqian Liang \\ Zhujiang College, South China Agriculture University Guangdong, Guangzhou, 510900
}

Keywords: Television Animation, Consciousness, Role Creation

\begin{abstract}
Animation is the movement of the image, is exaggerated deformation of the art, there is a wealth of performance content and a variety of means of expression. Film and television animation as one of the important forms of expression, is beyond the reality of the film, it created a virtual free time and space, giving a new visual experience, has always been a unique artistic charm. In the film and television animation, the role is the core, is a key to the success of animation, embodies the prototype consciousness, and in the design creation to follow a certain law. This paper attempts to find out the common and individuality of animated character creation from the perspective of animation art.
\end{abstract}

\section{Introduction}

Animation is a special film, the narrative, styling and cinema organic integration, the formation of a new comprehensive art. The animation focuses on a simple, full of fantasy, but has a profound idea of the story; the use of lines, patches, sounds, sports and other modeling elements to create a novelty and funny image; and animation-specific audio-visual language and montage Combined to create beyond the reality of the illusory world. The nature of animation is not the reality of the film's real reality of the recovery, but the deformation of material reality, with a high degree of illusory and hypothetical. The cartoon creates a world of deification of the deification of reality. In this world, people's entertainment, curiosity, fantasy psychological needs are met, the emotional desire to be released, the collective consciousness of the collective consciousness of the human collective unconscious. Animation art to create a defamiliar animated image, to bring people the pleasure of the senses. Animated screen or the screen appears on the characters, animals, plants, monsters and a variety of objects, events, the environment, its shape, action, sound, the plot is the audience in real life has not seen, completely strange, can cause Audience interest. Aristotle said: Surprise gives pleasure and is impressive. Animation art to create a strange world, and the common practice of the formation of a strong contrast, so that the audience from the sensory pleasure. It is precisely because of this, animation is not only the favorite children, but also attracted many adult viewers. The animated art reflects the collective unconscious content of the human beings, giving the audience emotional sympathy. The deep unconsciousness of mankind always gathers certain emotional desires, which are constrained in the real world and can not be met. Animated works as a completely free image, to create a free world to meet the emotional needs of the audience, people from the psychological balance to balance, from harmony to harmony. Inanimate animation constitutes a living image and life form, it is human life, self-knowledge, in the emotional resonance on the basis of the realization of the soul beyond, the inner meaning of the original meaning of purification.

\section{Animated Character Classification}

With the development of animation technology, animation character image of different styles, there are a variety of classification methods. People role film and television animation is based on a lot of historical stories, myths and legends or real life, which has a variety of characters. Such as "Prince of Egypt", "wind in the edge", "firefly tomb", "crayon", "Nezha downtown", "Final 
Fantasy", "magic Bisi ring" and other animation, Or completely realistic, or exaggerated to simplify, but are basically in line with the proportion of human body structure, shape and reality are similar.

Animal characters the film and television animation often takes place in the real world of the story grafted to animals. Such as "Lion King" adapted from Shakespeare's masterpiece "Hamlet". Animals in film and television animation often have human emotions, but also animal habits, more popular than the characters. "Small tadpole to find her mother", "deer plague", "insect bug", "seabed mobilization", "Madagascar" and so are the animal as the main role of the work.

Abstract characters some animation to nature in the absence of life or abstract things as the protagonist, simplicity of modeling. "Fantasia" will be displayed with symbols symbols, "needle line brain" in the free shape of the wool, "free light" in the light footprint is also an abstract role.

Other characters some characters themselves do not have life, animation master will be anthropomorphic treatment, so that it has the characteristics of mankind. Such as "Cars" in the car. There are some animations to monsters as the main characters, such as "monster Shrek", "monster", "baba dad" and so on, they and animal roles have similar characteristics.

\section{The Aesthetic Characteristics of the Role of Film and Television Animation}

The character of film and television animation is often simple, distinctive, contradictory conflict, most can be used to sum up the word. Such as "good" Snow White, "evil" queen, "brave" pony king, "naughty" crayon and so on. This simplified treatment, in line with the psychological acceptance of children, so that the role closer to the prototype, while allowing the audience easier to grasp the role of character traits. With the expansion of the animated audience, adults gradually joined the ranks of the animated audience, in order to meet the majority of the audience appreciate the taste, a lot of animation story complex, the role of personality multiple. But compared to other film and television works, animation character is still simple and clear, easy to understand, in line with the age of the aesthetic taste.

Animation modeling elements relative to other categories of video and television is the most simple, the original image of a high degree of generalization and refinement, animation character modeling characters generally by lines and patches to complete, even with complex three-dimensional technology synthesis, the role of the image is also very concise. Simple highlight the focus on the performance of the character character of the part of the exaggeration to enlarge, so that the audience never forget. "Crayon Shinchan" role modeling is a few simple geometric shapes, extremely simple, in order to highlight the characteristics of children's body, zoom in the small new head, the proportion of the head about the body 1/2. Facial features are also composed of simple graphics, mouth made a tilt treatment, an increase of humorous playful elements.

Animation role is virtual, the role of performance is also designed by the creator, often focus on personalized processing. Personalization is bound to use exaggerated approach, the role of animation language, action, expression mostly done exaggerated performance. In the animation for the "Donald Duck and Mickey Mouse" voice, Li Yang, Dong Hao change their voice qualities, deliberately pursue artistic effect; a lot of animation for the exaggerated speed, the role of escape behind a group of smoke or arc said; Crying performance is more classic, usually face imbalance, from the eyes out of the two "river." Moderate exaggeration makes the performance simplified, outstanding personality.

Animation character modeling and performance design is relatively simple, but simple highlights the focus, attention to detail of the characterization. In the visual, pay attention to the role of character and national characteristics of the characteristics of things, "Havoc in the Temple" in the shape of the Sun Wukong is drawing on the Peking Opera, Sun Wu Kong's every move also has the characteristics of Peking opera style. Animals often also focus on the role of the representative action or language. When you think about the problem, always with two fingers of the index finger in the head circle, "here, here, rest, rest" is also the end of each episode will inevitably appear concluding remarks. These actions and language affect generations of children. 


\section{Prototype Awareness of the Film and Television Animation Role Creation}

Animation stories are often specific or representative. The story of film and television animation on the one hand comes from the fairy tale, classical literary works, on the other hand also the author based on the original real life. In the adaptation, the general selection of characters prominent character, easy to use animation performance of the story, such as "Hamlet" adapted from the "Lion King", by the Bible "Exodus" to change the "Prince of Egypt" by "Notre Dame" Change the "bell tower camel man" and so on. The original works of these literature itself is a classic works, with a high literary and artistic value, which adapted the animated story contradictory sharp, save the kingdom, defeat the evil and other events of intense conflict, making the role of vivid, shocking. "Snow White", "beauty and the beast", "Cinderella" and so on itself is a fairy tale, in line with children's appreciation of psychology, Snow White, Cinderella and other roles expressed people's good and beautiful pursuit.

There are some animated stories from the original screenwriter, combined with the characteristics of modern society, select some full of legendary or humorous witty events. "Cats", "Crayon Shinchan", "Big Head Son Little Dad" and other animation Although the performance of ordinary people's ordinary life, but each story is representative. To "big head son little father", for example, each episode through a simple animation plot describes an event, tells a truth. These typical stories focus on the character of the character.

The so-called environment to create people, the role of life environment and the fate of the role of a direct relationship. Animation art is a virtual art, film and television animation environment is animated screenwriter artificially constructed. "Lion King" will be "Hamlet" story set in the African grassland animal world, the vast grassland is full of life, but also full of battle, in the battle and suffering, the small lion slowly grow into a lion king. When the sun rises from the horizon, it shines on the land of the prairie, The strange and familiar image of the Lion King aroused the audience's strong aesthetic desire. "Monster Company" set the story in the fantasy world of the monster, the bizarre world also means that the story and the role of the unusual, making the monster made its natural and easy to accept. "McDull Story" tells the story of a single-parent family in Hong Kong, the environment seems to be normal, but reflects the living conditions of Hong Kong citizens, in this environment, although the performance of McDull mother and son, but also can arouse the common people's resonance. Animation art is simple and straightforward, the animation story of the environment is typical, whether it is grassland, the future world, or the public life, these environments are representative of the role of activities to provide the necessary space and power to promote the plot forward.

Design the typical action is not limited to the protagonist. For the protagonist to design a typical action can be better performance character, description of identity; for the supporting design of the typical action can make the role of distinction with other characters, in the case of less performance of its characteristics. The protagonist of the typical action generally appear in the critical moment, you can use this action to get strength or wisdom; supporting the typical action is generally humorous and funny, as the animation in the funny episodes appear.

In addition to the special nature of the action, in the film and television animation, many animated characters also have their own sign language. "Here, rest here, rest, rest", every heard this sentence, will think of a clever break; "give me strength, I was Shirley", the American animation "magical princess - "This sentence in the classic lines to Shirui became a lot of children's animation idol;" can Li Li, Baba change ", which is the French cartoon" Baba father "in the lines, a time to become children Mantra. These classic languages make the animated characters deeply rooted and better characterize the character image. In addition to the special lines, animation dubbing is often full of fun. Disney animation "Donald Duck and Mickey Mouse" is not only animated story full of comedy, the Chinese version of the voice is also unique style. Li Yang and Dong Hao's voice became the Donald Duck and Mickey Mouse logo, for the Donald Duck and Mickey Mouse pave the way to the star. So in the animation production, dubbing is one of the key link. 


\section{Conclusion}

Animation is a dream into the reality of the factory, you can use countless interpretation of the way to show the imagination of the world of fantasy world. Animation role as the core of film and television animation art, carrying the creator of the persistent pursuit of animation and hard sweat, but also the audience awareness of animation, accept animation, like the entrance of animation. Animation is full of imagination, free and casual, but the role of the creation of rules to follow. This paper focuses on the author's understanding of the role of animation in the practice and theory exploration, analyzes the influence of archetypal consciousness on the creation of animation characters, and summarizes the law of animation character creation.

\section{References}

[1] Liang Yaming."Journal of Henan University of Science and Technology, 2007 (03)). [J]. Journal of Henan University of Science and Technology, 2007 (03)

[2] Liang Nan. China's FLASH animation industry road [J]. Journal of Zhejiang University of Science and Technology. 2007 (03)

[3] Guo Xiaoying. On the animated character image of the artistic design characteristics and artistic value [J]. The United States and the times. 2007 (04)

[4] Peng Xiaotao. Analysis of the characteristics of the animated image [J]. Modern commerce industry. 2007 (02)

[5] Yuan Xiaoli. Cartoon drama character modeling techniques [J]. Theatrical Monthly. 2006 (05) 